\title{
Meat quality of cattle subjected to period of aging process: a cross-heifer study
}

\section{Qualidade da carne de bovinos submetida ao processo de maturação: estudo com novilhas cruzadas}

\author{
Lucy Mery Antonia Surita ${ }^{1 *}$; Marina de Nadai Bonin Gomes²; Brayan Dias Dauria ${ }^{3}$; \\ Rodrigo da Costa Gomes ${ }^{4}$; Marília Williani Filgueira Pereira5; \\ Maria da Graça Morais²; Marjorie Toledo Duarte2; Luis Carlos Vinhas Ítavo2; \\ André Luiz Julien Ferraz ${ }^{6}$
}

\section{Highlights}

Tenderness of meat is a much-appreciated characteristic by consumers.

Qualitative attributes of meat were influenced by aging.

Meats evaluated after seven days of aging had lower shear force.

\begin{abstract}
The aim of this study was to evaluate the effects of aging on meat quality of crossbred heifers. Qualitative and quantitative evaluations of carcasses and meat of 148 crossbred heifers with an average age of 13 months and $407.5 \pm 29.22 \mathrm{~kg}$ body weight at slaughter were performed. After cooling for $24 \mathrm{~h}$, the carcasses were evaluated for hot carcass weight, $\mathrm{pH}$, conformation, physiological maturity, finishing, fat distribution, and length. Characteristics, such as $\mathrm{pH}$, color, marbling, exudation, as well as cooking losses, percentage of ether extract, and shear force were evaluated in meat at time zero and after seven days of aging. The carcasses displayed satisfactory results for parameters such as $\mathrm{pH}$ at $24 \mathrm{~h}$ of cooling $(\mathrm{pH} 24)$, finishing, distribution of fat, and subcutaneous fat thickness $(5.58,3.27,2.40$, and $6.62 \mathrm{~mm}$, respectively). The meat had a low marbling score (5.08) and percentage of ether extract (1.71), indicating that the meat was
\end{abstract}

1 PhD Student of the Course of the Graduate Program in Animal Science, College of Veterinary Medicine and Animal Science, Federal University of Mato Grosso do Sul, UFMS, Campo Grande, MS, Brazil. E-mail: lucymerysurita@hotmail. com

2 Profs., College of Veterinary Medicine and Animal Science, UFMS, Campo Grande, MS, Brazil. E-mail: marina.bonin@ ufms.br; marjorie.duarte@ufms.br; morais.mariazinha@gmail.com; luis.itavo@ufms.br

${ }^{3}$ PhD Student of the Graduate Program in Animal Science and Pasture, School of Agriculture Luiz de Queiroz, University of São Paulo, USP, Piracicaba, SP, Brazil. E-mail: brayandauria@hotmail.com

${ }^{4}$ Researcher, Brazilian Agricultural Research Corporation, Embrapa Beef Cattle, Campo Grande, MS, Brazil. E-mail: rodrigo.gomes@embrapa.br

${ }^{5}$ Post-doctorate Student of the Raduate Program in Animal Science, College of Veterinary Medicine and Animal Science, UFMS, Campo Grande, MS, Brazil. E-mail: marilia.filgueira@hotmail.com

${ }^{6}$ Prof., State University of Mato Grosso do Sul, UEMS, Aquidauana, MS, Brazil. E-mail: splinter@uems.br

* Author for correspondence

Received: Apr. 09, 2020 - Approved: Dec. 03, 2020 
relatively lean. Exudation and cooking losses showed similar results at zero and seven days of aging. The meat subjected to seven days of aging showed higher lightness and hue ( 40.98 and 0.77 , respectively) and tenderness of $5.25 \mathrm{~kg}$. These results indicated that aging affected meat color and shear force parameters; the meat of cross-heifers was softer but less red after maturation.

Key words: Marbling. Shear force. Tenderness. Young cattle.

\section{Resumo}

O objetivo deste estudo foi avaliar os efeitos da maturação na qualidade da carne de novilhas mestiças. Foram realizadas avalações quali-quantitativas de carcaças e carne de 148 novilhas mestiças com idade média de 13 meses e 407,5 $\pm 29,22 \mathrm{~kg}$ de peso corporal ao abate. Após resfriamento por 24 horas, as carcaças foram avaliadas quanto ao peso da carcaça quente, $\mathrm{pH}$, conformação, maturidade fisiológica, acabamento, distribuição de gordura e comprimento. Características como pH, cor, marmoreio, perdas por exsudação, assim como perdas por cocção, porcentagem de extrato etéreo e força de cisalhamento foram avaliadas na carne no tempo zero e após sete dias de maturação. As carcaças apresentaram resultados satisfatórios para parâmetros com pH em 24 horas de resfriamento $(\mathrm{pH} 24)$, acabamento, distribuição de gordura e espessura de gordura subcutânea $(5,58,3,27,2,40$ e 6,62 mm, respectivamente). A carne apresentou baixo índice de marmoreio $(5,08)$ e porcentagem de extrato etéreo $(1,71)$, indicando que a carne era relativamente magra. As perdas por exsudação e cozimento apresentaram resultados semelhantes aos zero e sete dias de maturação. A carne submetida a sete dias de maturação apresentou maior luminosidade e hue (40,98 e 0,77, respectivamente) e maciez de 5,25 kg. Esses resultados indicaram que a maturação afetou os parâmetros de cor da carne e a força de cisalhamento; a carne das novilhas cruzadas ficou mais macia, mas menos vermelha após a maturação.

Palavras-chave: Bovinos jovens. Força de cisalhamento. Maciez. Marmoreio.

\section{Introduction}

The demand of Brazilian consumers for superior meat cuts is steadily increasing. Despite high productivity, Brazilian beef presents a significant variability in its characteristics, especially in terms of tenderness, an undesirable factor in marketoriented products that requires maintenance of constant quality standards.

In order to meet the requirements of superior beef quality, exploring the maturity of crossbred females to allow early slaughter of young animals for improvement of their finishing characteristics, becomes a promising alternative to supply the market (Berg \& Butterfield, 1976).
In addition, implementation of postslaughter techniques such as ripening enables sensory improvement of meat (Nassu, Bernardi, Tullio, Cruz, \& Alencar, 2013). Maturation involves proteolysis of structural components of myofibrillar proteins present in muscle tissue (Kirinus, Fruet, Teixeira, Dorr, \& Nornberg, 2014) under controlled conditions, in which fresh meat is vacuum- packed and kept at temperatures of -1 to $2{ }^{\circ} \mathrm{C}$ for several days (Nassu et al., 2013); this process causes tenderization of meat and enables standardization of its tenderness.

Hence, the aim of this study was to evaluate the influence of aging on qualitative characteristics of meat of crossbred heifers. 


\section{Materials and Methods}

\section{Carcass and muscle samples}

Carcasses and longissimus muscle samples from 148 heifers ( $1 / 2$ Angus $\times 1 / 2$ Nellore) with an average age of 13 months and $407.5 \pm 29.22 \mathrm{~kg}$ body weight were used. The animals were slaughtered from February 2015 to February 2016 in a commercial abattoir following sanitary hygiene conditions and humanitarian slaughter norms (Ministério da Agricultura Pecuária e Abastecimento [MAPA] 2000).

\section{Evaluation of carcasses}

After cooling for $24 \mathrm{~h}$ at a temperature between $0^{\circ} \mathrm{C}$ and $2{ }^{\circ} \mathrm{C}$, the carcasses were evaluated qualitatively and quantitatively (Muller, 1987; Ministério da Agricultura Pecuária e Abastecimento [MAPA] 1989). Hot carcass weight was obtained at the end of slaughter. The left and right half carcasses were weighed and their values added.

Conformation was evaluated with scores assigned in a range from 1 to 18: lower (1-3), bad (4-6), fair (7-9), good (10-12), very good (13-15), and the highest (16-18).

Physiological maturity (Mat Phys) was obtained using a scale of 1 to 15 points, divided into classes $A$ to $E$, and into minor, medium, and major subclasses, where, $1=$ older animals and 15 = younger animals.

To evaluate the finish, a scale of 1 to 5 points was used: 1 (absent), scarce (1-3 mm), 3: medium (above 3 to $6 \mathrm{~mm}$ ), 4: uniform (above 6-10 mm), and 5 excessive (more than $10 \mathrm{~mm}$ ). Distribution of the covering fat was estimated using a scale of 1 to 3 points, where, 1 = uneven, $2=$ medium and $3=$ uniform .

The carcass length was determined with a millimeter tape measure by comparing the distance from the anterior border of the pubic bone to medial cranial border of the first rib.

\section{Meat quality}

$\mathrm{pH}$, rib eye area, subcutaneous fat thickness, marbling, color, and ether extract

After cooling the carcasses for $24 \mathrm{~h}$ at a temperature between 0 and $2{ }^{\circ} \mathrm{C}$, the $\mathrm{pH}$ (designated in this study as $\mathrm{pH} 24$ ), rib eye area (REA), subcutaneous fat thickness (SFT), marbling (MAR), and color measurements using the CIELab color scale were evaluated in the Celia 12th rib region of the longissimus muscle.

pH24 was measured using a Hanna Model HI 99163 digital $\mathrm{pH}$ meter equipped with a carcass/meat-specific penetration probe, in samples subjected to 0 and 7 days of aging (designated as $\mathrm{pHO}$ and $\mathrm{pH} 7$, respectively).

REA was determined by drawing the area on a parchment paper. It was then scanned and cut to obtain the area with the help of a LiCor Model 3100 Area Meter and expressed in $\mathrm{cm}^{2}$.

SFT (cm) was evaluated using a digital caliper between the 12th and 13th ribs of the longissimus muscle.

Marbling score was determined according to United States Department of Agriculture [USDA] (1965) standard, adapted by Muller (1987), with six rating scales: traits (1 
to 3 ), light (4 to 6$)$, small (7 to 9), medium (10 to 12 ), moderate (13 to 15$)$, and abundant (16 to 18), and divided into three subclasses - less, medium, and more.

Regarding color evaluation, the samples were exposed to atmospheric air for 20 min before estimating the myoglobin content. Color was determined by averaging three measurements taken at three points from each sample with the aid of a portable MiniScan XE Plus Hunterlab colorimeter with a D65 light source and $10^{\circ}$ reading angle for the following characteristics: L * (lightness), a * (redness), b * (yellowness) using the CIELab system. The instrument was calibrated with a white standard $\left(L^{*}=93.30, a=-0.89, b^{*}=0.95\right)$ and a black standard $\left(L^{*}=1.19, a^{*}=1.27, b^{*}=1.92\right)$.

From the values of $a{ }^{*}$ and $b *$, the values of chroma and hue were calculated (Macdougal, 1994) as follows:

$$
\begin{aligned}
& \text { Chroma }=\sqrt{\left((a *)^{2}+(b *)^{2}\right)} \\
& \text { Hue }=\tan ^{-1} \frac{b *}{a *}
\end{aligned}
$$

where, $a^{*}=$ chroma ranging from green (-) to red $(+) ; b *$ chroma ranging from blue $(-)$ to yellow $(+)$; tan $=$ tangent.

Measurements of losses by exudation and cooking, shear force, and ether extract

Two longissimus samples from the $12^{\text {th }}$ rib region, in the caudal cranial direction, were subjected to shear force (SF), exudation losses (EL), and cooking losses (CL) at zero and seven days of maturation. A third sample was collected for evaluation of intramuscular fat percentage or ether extract (EE).

The sample at zero days of aging was immediately frozen at $-18{ }^{\circ} \mathrm{C}$ and the other sample matured for seven days at $2-3^{\circ} \mathrm{C}$ and subsequently frozen at the same temperature and preserved in these conditions for no longer than 30 days.

Defrost exudation losses, cooking, and shear force were performed according to methods described by the American Meat Science Association [AMSA] (2015). Exudates were obtained after thawing the samples in a refrigerator at $2-5{ }^{\circ} \mathrm{C}$ for $24 \mathrm{~h}$. The exudates present in the packages and the steaks were weighed individually to obtain the weight loss after thawing and expressed as a percentage.

To determine cooking losses, the samples were weighed raw and subsequently roasted using an upper and lower resistance electric oven, preheated to $163{ }^{\circ} \mathrm{C}$, until the internal temperature of each sample reached $42{ }^{\circ} \mathrm{C}$. Next, the samples were turned and kept in the oven until the internal temperature reached $71{ }^{\circ} \mathrm{C}$. After roasting, the samples were weighed immediately to obtain weight loss after cooking (WCok) by calculating the proportion of difference in the initial weight (Wi, before cooking) and final weight (Wf, after cooking) using the following equation:

$$
\text { WCok } \%=\frac{\mathrm{Wi}-\mathrm{Wf}}{\mathrm{Wi}}
$$

where, WCok= weight loss after cooking; $\mathrm{Wi}=$ initial weight; $\mathrm{Wf}=$ final weight.

SF was obtained by removing six cylindrical subsamples measuring $1.27 \mathrm{~cm}$ in diameter by $2.54 \mathrm{~cm}$ in length from the inner part of each steak. The subsamples were extracted parallel to the axis of the muscle fibers with the aid of a pan attached to a Schulz Pratika bench drill and sheared using a texturometer (TA.XT.Plus Texture Analyzer) equipped with a 
Warner Bratzler shear blade. Tenderness value of each sample was represented by calculating the arithmetic mean of the shear force values obtained in the six subsamples. These procedures were repeated for all samples corresponding to the two maturation periods.

Evaluation of ether extract or intramuscular fat percentage was performed using the method described by the American Oil Chemists' Society [AOCS] (2009) with an automatic extraction system using ether, high temperature, and pressure (ANKOM XT15 Extractor, ANKOM Technology, Macedon, USA).

\section{Data analysis}

The experimental design used was completely randomized. The Univariate SAS procedure was used to characterize the carcasses and meat of the heifers, and correlation studies were carried out among the variables analyzed.

The effect of maturation on meat quality was analyzed in a model containing fixed effects of maturation (without and with maturation) using the following equation:

$$
\mathrm{j}^{\mathrm{JK}}=\mu \pm \operatorname{trat} \mathrm{i} \pm \mathrm{ei}^{\mathrm{Jk}}
$$

where, $\mathrm{j}^{\mathrm{JK}}=$ observed variable; $\mu=$ constant inherent to observations; trat $\mathrm{i}=$ ripening time effect (zero and seven days); ei $\mathrm{i}^{\mathrm{jk}}=$ random error regarding observation $\mathrm{i}^{\mathrm{jk}}$.

For comparison between means, we used the Tukey test at 5\% significance.

\section{Results and Discussion}

\section{Carcass measurements}

The $\mathrm{pH}$ values observed in our study $24 \mathrm{~h}$ after slaughter and in matured and nonmatured meat (Table 1) could be considered as normal (Mach, Bach, Velarde, \& Devant, 2008) and adequate to guarantee organoleptic characteristics. This indicated proper preslaughter management of animals (Muchenjea et al., 2009).

The carcasses showed satisfactory results (Table 1), with fat coverage above the minimum levels required by the industry ( 3 to $6 \mathrm{~mm}$ ) and displayed average distribution, thereby giving a good finish to the carcasses (median) and offered protection against dehydration during cooling. Thus, reduction of tenderness and an increase in the loss of liquid from the meat that makes meat less acceptable to consumers was prevented (Burin, 2016).

\section{Meat quality}

The amount of intramuscular fat assessed by either the subjective (marbling) or objective (ether extract) methods suggested that the meat samples were relatively lean, indicating little intramuscular fat deposition (Table 1). The marbling score evaluated in this study (Light + ) is related to meat with intramuscular fat percentage between 3.1 and 3.9 (Lonergan, Topel, \& Marple, 2019) higher than that observed in this study. 
Table 1

Descriptive statistics of carcass and meat qualitative characteristics at 0 and 7 days of aging measured in crossbred heifers slaughtered at thirteen months of age

\begin{tabular}{|c|c|c|c|c|}
\hline Variable & Mean & $\mathrm{SD}$ & Minimum & Maximum \\
\hline pH24 & 5.58 & 0.12 & 5.25 & 5.87 \\
\hline Hot carcass weight, kg & 215.15 & 17.75 & 179.00 & 270.50 \\
\hline Conformation ${ }^{1}$ & 8.95 & 1.31 & 5.00 & 12.00 \\
\hline Finishing ${ }^{1}$ & 3.27 & 0.65 & 1.00 & 5.00 \\
\hline Distribuition ${ }^{1}$ & 2.40 & 0.49 & 1.00 & 3.00 \\
\hline MatPhys ${ }^{1}$ & 13.36 & 1.87 & 10.00 & 15.00 \\
\hline Carcass length, $\mathrm{cm}$ & 122.43 & 3.77 & 115.00 & 134.00 \\
\hline Subcutaneous fat thickness, $\mathrm{mm}$ & 6.62 & 2.77 & 2.11 & 15.84 \\
\hline Rib eye area, $\mathrm{cm}^{2}$ & 77.15 & 10.73 & 54.91 & 104.66 \\
\hline Marbling score ${ }^{1}$ & 5.08 & 2.64 & 1.00 & 13.00 \\
\hline Ether extract, \% & 1.71 & 0.90 & 0.20 & 4.62 \\
\hline \multicolumn{5}{|c|}{0 days of aging } \\
\hline $\mathrm{pHO}$ & 5.49 & 0.13 & 5.25 & 5.84 \\
\hline Lightness0 & 38.36 & 2.79 & 30.34 & 44.39 \\
\hline Chroma0 & 20.01 & 1.46 & 15.78 & 23.22 \\
\hline HueO & 0.70 & 0.04 & 0.60 & 0.82 \\
\hline Exudation losses0, \% & 6.1 & 2.09 & 2.21 & 12.21 \\
\hline Cooking losses $0, \%$ & 27.73 & 4.29 & 17.27 & 50.03 \\
\hline Shear Force0, kg & 8.24 & 2.06 & 4.37 & 13.56 \\
\hline \multicolumn{5}{|c|}{7 days of aging } \\
\hline $\mathrm{pH} 7$ & 5.54 & 0.16 & 4.48 & 5.81 \\
\hline Lightness7 & 40.15 & 2.55 & 33.32 & 46.76 \\
\hline Chroma7 & 19.41 & 1.79 & 14.99 & 23.61 \\
\hline Hue7 & 0.75 & 0.06 & 0.61 & 0.95 \\
\hline Exudation losses7, \% & 5.97 & 1.79 & 2.73 & 10.26 \\
\hline Cooking losses7, \% & 27.19 & 5.33 & 20.02 & 44.81 \\
\hline Shear Force7, kg & 5.89 & 2.01 & 2.56 & 12.62 \\
\hline
\end{tabular}

$\mathrm{SD}=$ Standard Deviation;

1 Conformation (scores from 1 to 18); Finishing (scale from 1 to 5); Distribution = fat distribution uniformity (scale 1 to 3 ); MatPhys = physiological maturity (scale 1 to 15); Marbling (score 1 to 18). 
Deposition of adipose tissue follows a gradual order, with intramuscular fat deposited last in a carcass (Alves et al., 2016). In a study with 15-month-old heifers, Fernandes et al. (2009) observed higher mean values of intramuscular fat than those observed in this study. These results suggest that older animals tend to have meat with higher amounts of intramuscular fat (Horst et al., 2016; Park et al., 2018).

Possibly, in our study, the low marbling score observed in the meat was due to the young age of the heifers at slaughter, in which accelerated intramuscular fat deposition may not have been initiated, despite having considerable deposition of subcutaneous fat (6.62 mm).

The meat coloration of heifers, assessed by means of lightness, chroma, and hue, at 0 and 7 days of aging was classified as clear (Table 1). Meat color is related to the myoglobin pigment and may be influenced by final $\mathrm{pH}$, age, physical activity, and intramuscular fat (Muchenjea et al., 2009). Color is an attribute that does not affect the palatability of meat. However, it is important in its marketing, since consumers consider color as an indication of freshness and quality (Ponnampalam et al., 2013), and tend to reject meat with a dark color (Ponnampalam et al., 2017).

As demonstrated by the sum of exudation and cooking losses, results were similar both at 0 and after 7 days of maturation (Table 1). Vaz et al. (2010) also reported cooking losses in a study with young crossbred heifers that are similar to our results. Lesser amounts of losses due to defrosting and cooking can be observed in meat of animals with higher fat deposition (Rubiano et al., 2009). The possible reason for liquid losses in beef heifers could be due to the higher protein content and proportionally lower fat content as observed by the low marbling score and ether extract.

In our study, the shear force at 0 days of aging classified heifer meat as hard; however, the hardness was reduced after 7 days of aging (Table 1). $\mathrm{pH}$ and fat cover are characteristics that can influence the tenderness of meat (Maciel, Amaro, \& Lima, 2011). Both these variables were within the limits that guarantee the quality of meat.

Intramuscular fat can indirectly influence meat texture, with a percentage of around $15 \%$ in the variability of tenderness of meat, attributed to an increase in the degree of marbling (Horst et al., 2016). It is worth noting that a significant loss of water during cooking may result in less juiciness and tenderness of meat, as measured by shear force. Lower percentage of marbling and loss of water may have contributed to the higher shear force in the meat of heifers at 0 day of aging.

By contrast, lower shear force of meat after a period of aging can be attributed to myofibril degradation by the enzymatic action of calpain (Lonergan, Zhang, \& Lonegan, 2010).

Correlation between carcass and meat characteristics

Correlation analysis between the evaluated characteristics (Figure 1) showed that the colorimetric variables displayed significant positive correlations. Correlation of lightness with hue $(r=0.85)$ and chroma $(r=$ 0.50 ) was observed, indicating that meat with better lightness (higher $L^{*}$ ) had a less red hue (higher hue) and lighter hue (low chroma). 


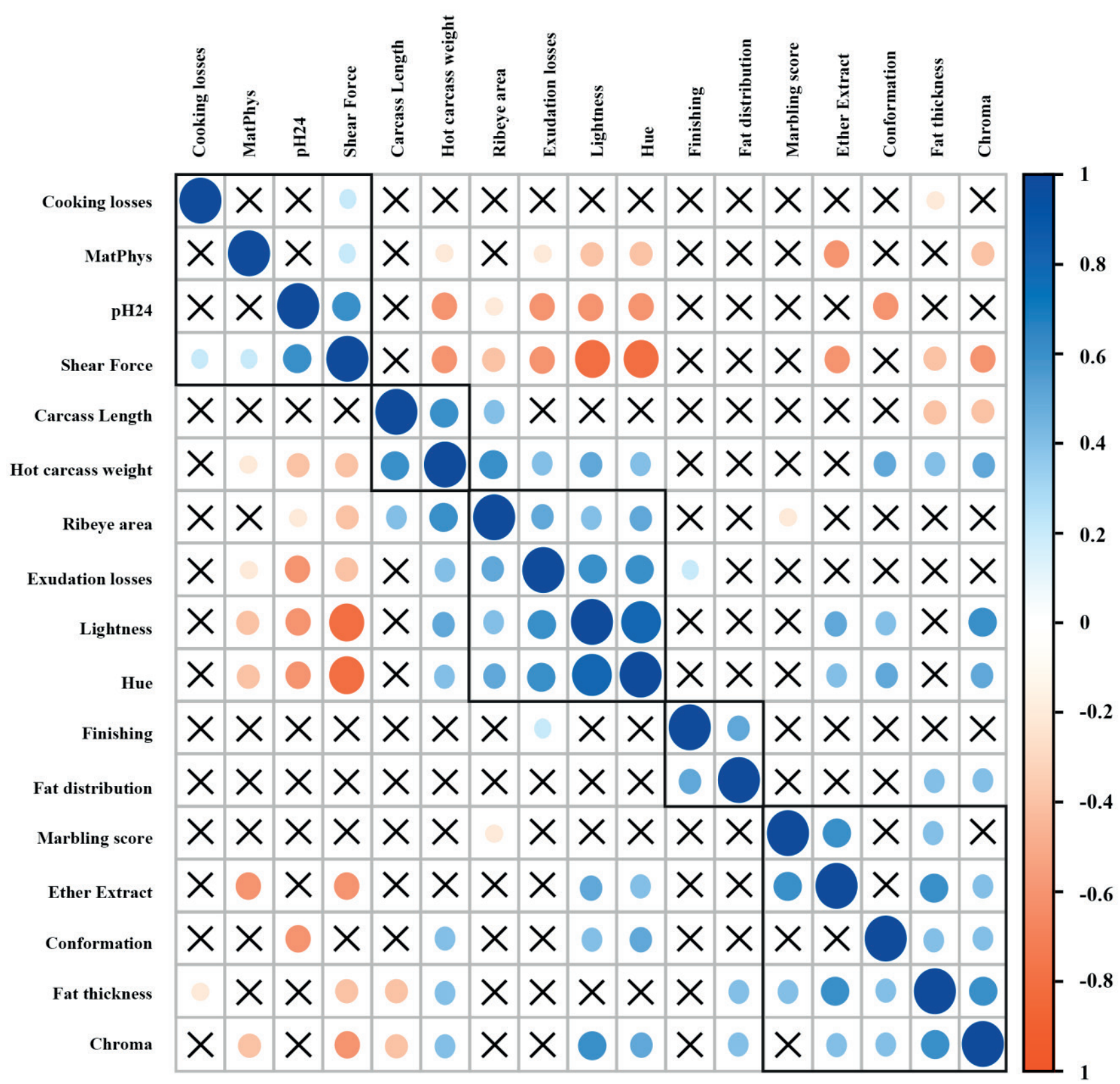

Figure 1. Correlations, according to clusters, between qualitative and quantitative variables of carcass and meat of Angus $x$ Nellore heifers slaughtered at 13 months of age. The color and size of the circle at the intersection between two variables indicate, as shown on the right, the sign and the size of the significant correlations $(P<0.05)$. X indicates that the observed correlation was not significant $(P>0.05)$. Inner rectangles indicate the formation of groupings of variables. 
Variables such as luminosity and hue were negatively correlated $(r=-0.59$ and $r=-0.57$, respectively) with shear force, indicating that darker and less-toned meat presented with higher hardness (Figure 1). Similarly, but less significantly, these variables were negatively correlated with $\mathrm{pH} 24$ after slaughter ( $r=-0.33$ and -0.33 , respectively) and carcass physiological maturity $(r=-0,26$ and -0.28 , respectively), indicating that older animals and/or those displaying a higher $\mathrm{pH}$ had inferior-looking meats. Moreover, lightness and hue showed a moderate correlation with loss of water via exudation $(r$ $=0.46$ and 0.51 , respectively), indicating that lighter meats tend to produce less exudates when packaged.
Notably, two positive correlations that denote some obviousness were observed between the hot carcass weight and the carcass length $(r=0.41)$ (Figure 1). This indicates that longer carcasses are also heavier. Marbling score and ether extract refer to intramuscular fat deposition. Correlation between these two variables $(r=0.43)$ shows that the marbling score was effective in predicting the amount of fat present in the samples.

\section{Effect of aging on meat of crossbred heifers}

We observed that the aging process resulted in lighter meats and exhibited lower shear force $(P<0.05)$ (Table 2).

\section{Table 2}

Influence of aging ( 0 day of aging or 7 days of aging) on meat quality of Angus $x$ Nellore heifers slaughtered at thirteen months of age

\begin{tabular}{lcccc}
\multicolumn{1}{c}{ Variable } & P-value & DP & $\begin{array}{c}\text { Mean } \\
\text { (0 day os aging) }\end{array}$ & $\begin{array}{c}\text { Mean } \\
\text { (7 days of aging) }\end{array}$ \\
\hline Exudation losses, \% & 0.3646 & 0.54 & 6.43 & 6.09 \\
Cooking losses, \% & 0.8227 & 0.01 & 22.11 & 22.30 \\
Ph & 0.1701 & 0.04 & 5.46 & 5.50 \\
Lightness & 0.0001 & 0.67 & $38.81 \mathrm{~b}$ & $40.98 \mathrm{a}$ \\
Chroma & 0.1308 & 0.47 & 19.42 & 18.92 \\
Hue & 0.0001 & 0.01 & $0.72 \mathrm{~b}$ & $0.77 \mathrm{a}$ \\
Shear force, $\mathrm{kg}$ & 0.0001 & 0.50 & $7.91 \mathrm{~b}$ & $5.25 \mathrm{a}$
\end{tabular}

$\mathrm{SD}=$ Standard Deviation;

$a, b$ - Line averages, followed by different letters, differ by Tukey test $(P<0.05)$.

Averages of color coordinates (lightness and hue) increased over time (Table 2); however, the average lightness observed at both the time-periods ( 0 and 7 days) was within the range described by Muchenjea et al. (2009) as ideal for beef (33.2-41.0).
By contrast, after a period of aging, there was an increase in luminosity, and consequently in hue, as observed by positive and high correlation $(r=0.85)$ between the two variables (Figure 1). The results indicate that higher the hue values, the less red and 
more yellowish the beef becomes; hence, in our study the increase in hue after seven days of storage negatively influenced the color of meat. These results suggest that the aging process provided a lesser intensity of red color to the meat, which is not attractive to consumers. However, it was beneficial in terms of improving the water-retention capacity of meat during storage, as observed by the lower exudate losses at seven days of aging.

The lower shear force $(5.25 \mathrm{~kg})$ observed after seven days of aging (Table 2 ) is related to proteolysis of structural components of myofibrils by the action of calcium-dependent proteases, which causes weakening of the sarcomere structure due to degradation of the Z-line, consequently resulting in the tenderization of meat (Bhat, Morton, Mason, \& Bekhit, 2018).

Similarly, Rodrigues et al. (2008) attributed the lower shear force observed after a period of aging in heifers of different genetic groups to the enzymatic action on the postmortem muscles and emphasized that the seven-day aging period of super-processed animals was sufficient to make meat tender. However, the shear force observed in our study was slightly higher than the limit of $5 \mathrm{~kg}$ to be considered as tender beef (Poleti et al., 2016).

Using different fillet samples matured for 14 and 21 days, Delgado, Aguiar, Ortega, Spoto, and Castilho (2006) classified meat as tender (SF $<4.1 \mathrm{~kg}$ ) or hard (SF > $4.8 \mathrm{~kg}$ ) to determine the perception of Brazilian consumers regarding bovine meat tenderness. The authors noted that $30.2 \%$ of consumers indicated softness as the most important attribute during consumption; overall, soft steaks scored higher. According to the authors, these results indicate the importance of the attribute of softness in the perception of Brazilian consumers, especially in relation to the shear force levels used in the study (3.2 and $6.6 \mathrm{~kg}$ ), which were close to the thresholds between soft and hard meat. Thus, regarding the pattern of tenderness that our consumers prefer, we can infer that the meat evaluated in this study can be considered to have a soft texture after a period of aging; however, other qualitative characteristics have to be considered before establishing the product in the market.

\section{Conclusion}

The texture of the meat of crossed heifers was softer after a period of aging; however, it displayed a lesser intensity of red color, which consumers may not find desirable.

\section{Acknowledgments}

The authors are grateful to the Fundação de Apoio ao Desenvolvimento do Ensino Ciência e Tecnologia do Estado de Mato Grosso do Sul (Fundect) for the financing of the project (Process 23/200.481/2014) and for the Msc grant (Process 23/200.551/2014) that allowed this study to be conducted; Embrapa Beef Cattle; Federal University of Mato Grosso do Sul and the State University Mato Grosso do Sul. "This study was financed in part by the Coordenação de Aperfeiçoamento de Pessoal de Nível Superior - Brasil (CAPES) - Finance Code 001" 


\section{References}

Alves, K. R., Silva, L. D. F., Ribeiro, E. L. A., Guerra, G. L., Paiva, F. H. P., \& Henz, E. L. (2016). Carcass characteristics, meat quality, feeding behavior of Nellore heifers fed diets containing sunflower pie. Acta Scientiarum Animal Sciences, 38(2), 183-190. doi: 10.4025/actascianimsci. v38i2.30183

American Meat Science Association (2015). Research guidelines for cookery. Sensory evaluation and instrumental tenderness measurements of fresh meat. Champaign, IL: American Meat Science Association.

American Oil Chemits' Society (2009). Official method am 5-04 - rapid determination of oil/fat utilizing high temperature solvent extraction. Additions and revisions to the official methods and recommended practices of the american oil chemits' society.

Berg, R. T., \& Butterfield, R. M. (1976). New concepts of cattle growth. Sidney: Sidney University Press.

Bhat, Z. F., Morton, J. D., Mason, S. L., \& Bekhit, A. E. A. (2018). Role of calpain system in meat tenderness: a review. Food Science and human Wellness, 7(3), 196-204. doi: 10.1016/j.fshw.2018.08. 002

Burin, P. C. (2016). Qualidade da gordura ovina: características e fatores de influência. Revista Eletronica de Veterinária, 17(10), 1-28. Recuperado de https://www.redalyc. org/pdf/636/63647454003.pdf

Delgado, E. F., Aguiar, A. P., Ortega, E. M. N., Spoto, M. H. F., \& Castilho, C. J. C. (2006). Brazilian consumers perception of tenderness of beef steaks classifield by shear force and taste. Science Agriculture,
63(3), 232-239. doi: 10.1590/S010390162006000300004

Fernandes, A. R. M., Sampaio, A. A. M., Henrique, W., Tullio, R. R., Oliveira, E. A., \& Silva, T. M. (2009). Composição química e perfil de ácidos graxos da carne de bovinos de diferentes condições sexuais recebendo silagem de milho e concentrado ou cana-de-açúcar e concentrado contendo grãos de girassol. Revista Brasileira de Zootecnia, 38(4), 705-712. doi: 10.1590/ S1516-35982009000400017

Horst, E. H., Neumann, M., Leão, G. F. M., Mareze, J., Mareze, M., Dochwat, A., \& Ueno, R. K. (2016). Aspectos que influenciam a maciez da carne de bovinos: Revisão. Publicações em Medicina Veterinária e Zootecnia, 10(11), 779-784. doi: 1022256/ pubvet.v10n10.779-784

Kirinus, J. K., Fruet, A. P. B., Teixeira, C., Dorr, A. C., \& Nornberg, J. L. (2014). Aplicação da genética molecular para a melhoria da qualidade da carne bovina. Revista Eletrônica em Gestão, Educação e Tecnologia Ambiental, 18, 165-174. doi: 10.5902/2236117013181

Lonergan, E. F., Zhang, W., \& Lonegan, S. M. (2010). Biochemistry of postmortem - lessons on mechanisms of meat tenderization. Meat Science, 86(1), 184195. doi: 10.1016/j.meatsci.2010.05.004

Lonergan, S. M., Topel, D. G., \& Marple, D. N. (2019). The science of Animal growth and meat technology (2a ed.). lowa: Academic Press.

Macdougal, D.B. (1994). Colour meat. In Quality attributes and their measurement in meat, poultry and fish products (pp.79-93). London: Blackie Academic \& Professional. 
Mach, N., Bach, A., Velarde, A., \& Devant, M. (2008). Association between animal, transportation, slaughterhouse practices, and meat pH in beef. Meat Science, 78(3), 232-238. doi: 10.1016/j.meatsci.2007.06. 021

Maciel, M. V., Amaro, L. P. A., \& Lima, D. M., Jr. (2011). Métodos avaliativos das características qualitativas e organolépticas da carne de ruminantes. Revista Verde de Agroecologia e Desenvolvimento Sustentável, 6(3), 1724. Recuperado de https://www.gvaa. com.br/revista/index.php/RVADS/article/ view/608/640

Ministério da Agricultura Pecuária e Abastecimento (1989). Portaria No. 612, 05 de outubro. Sistema nacional de tipificação de carcaças bovinas. Brasília, DF.

Ministério da Agricultura Pecuária e Abastecimento (2000). Instrução Normativa No. 3, 17 de janeiro. Estabelece regulamento técnico de métodos de insensibilização para o abate humanitário de animais de açougue; e dá outras providências. Diário Oficial da União, Brasilia, DF, 1, 14-16.

Muchenjea, V., Dzama, K., Chimonyo, M., Strydom, P. E., Hugo, A., \& Raats, J. G. (2009). Some biochemical aspects pertaining to beef eating quality and consumer health: a review. Food Chemistry, 112(2), 279-289. doi: 10.1016/j.foodchem.2008.05.103

Muller, L. (1987). Standards for carcass evaluation and tendering of steers (2a ed.). Santa Maria, RS: UFSM.

Nassu, R. T., Bernardi, M. R. V., Tullio, R. R., Cruz, G. M., \& Alencar, M. M. (2013).
Qualidade e perfil sensorial descritivo da carne maturada proveniente de animais cruzados. Ata de Saúde Ambiental, 1(1), 13-25. Recuperado de https://pesquisa. bvsalud.org/portal/resource/pt/vti-22017

Park, S. J., Beak, S. H., Jung, D. J. S., Kim, S. Y., Jeong, I. H., Piao, M. Y.,... Baik, M. (2018). Genetic, management, and nutritional factors affecting intramuscular fat depositions in beef cattle - a review. Asian-Australasiasn Journal of Animal Sciences, 31(7), 1043-1061. doi: 10.5713/ ajas.18.0310

Poleti, M. D., Rosa, A. F., Vignato, B. S., Moncau, C. T., Perez, B. C., Ventura, R. V.,... Balieiro, J. C. C. (2016). Mudanças proteolíticas em músculo de bovinos Nelore durante o processo de maturação. Anais do Simpósio de Pós-graduação e pesquisa em nutrição animal, Pirassununga, SP, Brasil., 10.

Ponnampalam, E. N., Holpkins, D. L., Bruce, H., Li, D., Baldi, G., \& Bekhit, A. E. (2017). Causes and contributing factors to dark cutting meat: current trends and future directions: a review. Comprehensive Reviews in Food Science and Food Safetyr, 16(201), 400430. doi: 10.1111/1541-4337.12258

Ponnampalam, E. N., Butler, K. L., Burnett, V. F., McDonagh, M. B., Joe, L., Jacobs, J. L., \& Hopkins, D. L. (2013). Aged vacuum packaged lamb cuts are lessbrown than fresh muscle cuts under simulated retail display. Food and Nutrition Sciences, 4(8), 147-153. doi: 10.4236/fns.2013.48A018

Rodrigues, E., Arrigoni, M. B., Jorge, A. M., Bianchini, W., Hadlich, J. C., Moreira, P. S. A., \& Martins, C. L. (2008). Características físicas e químicas da carne de novilhas de diferentes grupos genéticos no modelo 
biológico superprecoce. Revista Brasileira de Saúde e Produção Animal, 9(3), 594604.

Rubiano, G. A., Arrigoni, M. B., Martins, C. L., Rodrigues, E., Gonçalves, H. C., \& Angerami, C. N. (2009). Performance, carcass characteristics and meat quality of Canchim, Nellore and their crossbred superbred cattle. Brazilian Journal of Zootechnics, 38(12), 2490-2498. doi: 10.1590/S1516-35982009001200027
United States Department of Agriculture] (1965). Official United States Standards for grades of carcass beef. Consumer and Marketing Service, Washington, DC.

Vaz, F. N., Restle, F., Arboite, M. Z., Pascoal, L. L., Alves, D. C., Fo., \& Pacheco, R. F. (2010). Carcass and meat characteristics of young steers and heifers supplemented in cultivated pastures. Animal Science Brasileria, 11(1), 42-52. doi: 10.5216/cab. vllil.5131 
